\title{
PERGERAKAN SOSIAL: ANTARA MARXIAN DAN NON MARXIAN
}

\author{
Adi Prasetijo ${ }^{1}$
}

\begin{abstract}
Social movement always has seen as the negative term in the ruling class or authority standpoint. They perceive social movements as destructive action, and to weaken social stability. However, those who oppose the ruling class said that social movements are necessary action to against authority. In this paper will see how the theoretical debate between Marxian and non-Marxian, in looking at social movements. This is including the role of intellectuals and the charismatic leaders; as well as ideological aspects ought to be discussed as part of a social movement theory paradigm debate.
\end{abstract}

\section{Keywords: Social Movement, Intellectual Role, Collective Action, Peasant}

\section{A. Pergerakan Sosial Dalam Debat}

$\mathrm{J}$ ika kita berdiskusi tentang perkembangan teori pergerakan social atau 'social movement' maka ada dua paradigma klasik yang menjadi background utamanya, yaitu tradisi Marxist dan teori klasik social movement yang non-Marxist. Teori Karl Marx bisa disebutkan teori klasik sosial yang mendiskusikan 'social movement atau pergerakan social secara modern. Meskipun Marx tidak mendefinisikan secara khusus atau menyebutkan tentang pergerakan sosial, namun sebagai 'collective action' atau tindakan kolektif. Namun pemikiran Marx tentang kelas sosial, perlawanan kelas sosial dan kesadaran kelas sosial banyak digunakan para ahli untuk menjelasan alasan munculnya 'social movement'.

'Social movement' atau pergerakan social dalam pandangan Marxist sesungguhnya adalah 'collective action' atau tindakan kolektif yang muncul sebagai reaksi atas kondisi ketertekanan yang dirasakan oleh kelas proletariat terhadap oleh kelas penguasa atau borjouisi.

Pandangan ini berbeda dengan teori social klasik 'social movement' yang nonMarxist, yaitu Durkhemian dan Weberian. Pemikiran para ahli non-Marxist, terutama kaum Durkhemian melihat 'social movement' adalah strategi adaptasi terhadap situasi dan kondisi social yang baru. Awalnya
Durkheim muncul dengan penjelasan 'behaviour collective', yang menjelaskan bahwa pergerakan sosial adalah hasil dari sifat anomali individu terhadap organisasi sosialnya atau sesuatu yang bersifat disorganization, mengganggu keseimba ngan social organisasi (Porta \& Diani, 1999).

Perkembangan berikutnya dalam pemahaman teori pergerakan social dalam tradisi non-Marxist ini berlanjut kepada pemahaman 'resource mobilization theory'. Dalam pandangan 'resource mobilization theory' atau teori mobilisasi sumber daya yang dikemukakan oleh Charle Tilly (1978), pergerakan social dianggap sebagai output dari 'rational choices' untuk mencapai tujuan pergerakan. Jadi dalam pemahaman ini maka pergerakan sosial dilihat sebagai bertemunya ketersedian sumber daya dan kemampuan invidu atau kelompok untuk mempengaruhi masyarakat mencapai tujuannya.

Dalam pandangan non-Marxist, pemahaman social movement jika awalnya dianggap sebagai sesuaitu yang negatif karena dianggap sebagai penghalang harmoni suatu masyarakat maka dalam teori mobilisasi sumber daya dianggap sebagai suatu yang normal dan strategi adaptasi yang harus dilakukan untuk mencapai tujuan. Hal ini berbeda dengan pandangan tradisi Marxian yang memandang bahwa social movement adalah collective action yang harus dilakukan karena merupakan

\footnotetext{
${ }^{1}$ Penulis adalah Direktur ICSD dan Dewan Anggota KKI Warsi periode 2014-2017
} 
suatu reaksi terhadap kondisi penindasan yang dilakukan oleh kelas penguasa. Social movement dalam pandangan Marxian dipandang sebagai suatu yang aktif untuk merubah keadaan, menjadi masyarakat yang tanpa kelas.

Debat ini kemudian memunculkan apakah peran dari inetelektual dalam pergerakan social karena siapa sesungguhnya punya peran dalam memicu revolusi atau pergerakan social, atau siapa yang menyadarkan dan membangkitkan kaum subordinate untuk melawan kaum penguasa.

\section{B. Kesadaran Untuk Melawan}

$\mathrm{M}$ arx menjelaskan bahwa untuk merubah keadaan, kaum kelas proletar haruslah dapat mengorganisir diri untuk melawan kaum kelas boujouis. Marx sendiri menyadari bahwa kesadaran haruslah dibangkitkan dari 'luar', dan ini juga diamini oleh pemikir Marx penerusnya, mulai dari Lenin, Gramsci, dan Eric Wolf, antropolog Marxian yang cukup menonjol dalam menuliskan tentang gerakan kaum peasant yang tertindas.

Marx juga mengenalkan pentingnya ideologi dalam perjuangan dalam kelas sosial. Ideologi disini digunakan sebagai alat acuan untuk melakukan perjuangan (Bottomore, 1979). Dalam beberapa literature, Marx sesungguhnya menyamakan ideology dan budaya. Dalam pemahaman Marx, budaya adalah nilai-nilai revolusi yang menjadi dasar untuk pergerakan dan inilah sebenarnya makna ideology (baca Lukacs, 1979).

Teori Marx ini kemudian diikuti dan diejawantahan oleh Lenin dan Gramsci. Lenin adalah penerus tradisi Marx yang kuat, baik dalam pemikiran dan praktek. la menggunakan pemahaman Marx untuk melakukan revolusi Bolshevik di Rusia(dalam Wilkinson, 1971).

Berbeda dengan Marx, yang percaya bahwa kesadaran kelas sosial akan tumbuh sendirinya akibat tekanan dari kelas borjuis, Lenin lebih menekanan kepada peran dan fungsi partai komunis sebagai ujung tombak dalam menggerakan kaum proletar atau kelas pekerja di Rusia. la menekankan kepada pengorganisasian sistem 'cell' oleh partai. Berbeda dengan Lenin, Gramsci menekanan kepada konsesus tujuan bersama yang akan dicapai dalam suatu social movement. Berbeda dengan dengan Marx dan Lenin, Gramsci menempatkan dimensi budaya dalam menjelaskan perjuangan kelas terhadap hegemony.

Gramsci (1972) dalam bukunya "Prison Notebooks" mengatakan bahwa hegemoni adalah suatu proses dominasi kesadaran yang dilakukan oleh kelas borjuis kepada kelas pekerja atau proletar melalui penanaman ideologi semu. Hegemoni ini dilakukan untuk tujuan memastikan bahwa kelas pekerja atau proletar bekerja sesuai dengan kehendak kaum borjouis tanpa ada perlawanan.

Hal ini dipelajari oleh Gramsci ketika ia melakukan pendampingan kepada kelas pekerja di Italia, dimana ia menemukan bahwa betapa ia sudah menjalankan garisgaris panduan partai dan apa yang telah dikatakan Marx. Gramsci kemudian memberikan contoh bagaimana proses kesadaran kelas gagal terjadi dikelas pekerja di Itali dimana menurutnya diakibatkan bahwa asal dari kelas pekerja tersebut bukanlah pure kelas pekerja namun dari kaum petani atau peasant yang bekerja dipabrik-pabrik. Jadi meskpun mereka bekerja sebagai buruh pabrik namun secara mentalitas dinilai oleh Gramsci masih dibayang-bayangi mentalitas peasant yang tidak bisa lepas dari bayangan hegemoni sehingga kesadaran kelas tidak muncul dan berubah menjadi pergerakan(dalam Sasson, 1980).

Kaum petani atau peasant ini memang tidak mempunyai tempat dalam cara pandang Marx. Mereka disebut oleh Marx sebagai kelompok kelas yang bodoh dan tidak berharga. Marx menyebut peasant sebagai "sack of potatoes"”. Namun Mao mempunyai pemikiran lain. la mengatakan bahwa kelas buruh atau proletar bukanlah satu-satunya penggerak revolusi. Dalam kasus Cina, kelas pekerja tidaklah ditemukan. Maka mereka harus bekerja dengan kaum petani. Seperti yang terjadi juga di Vietnam.

Kelas petani ini menurut Marx tidak mempunyai kesadaran untuk bergerak memperjuangkan kelasnya karena pengaruh kelas borjousi yang sangat kuat ke mereka melalui penanaman kesadaran semu (false consciousness) yang kuat. Kondisi seperti ini disebut dalam Marx sebagai suatu 
kondisi 'alienasi' atau kondisi termarginalkan(Israel, 1979). Kondisi alienasi ini menurut Marx adalah suatu kondisi dalam mode of production dalam industri dimana kelas pekerja tidak menyadari bahwa mereka telah digunakan oleh kelas pemilik modal untuk melakukan suatu produksi tanpa mereka sendiri menikmati keuntungan secara penuh dari surplus values atau nilai keuntungan antara - dari harga barang yang diproduksi dan dijual oleh para kapitalis. Kondisi alienasi ini adalah kondisi yang selalu dilakukan oleh kaum kapitalis kepada kaum pekerja dengan cara mengeksploitasi sumber daya tenaganya.

Eric Wolf (1969) mempunyai pandangan yang berbeda tentang kaum petani ini. Dari kajiannya tentang revolusi petani mengatakan bahwa kelompok peasant mempunyai peranan yang besar dalam revolusi didaerahnya masing-masing. Seperti yang terjadi di Cina, Kuba, Mexico dan daerah-daerah lainnya. la melihat bahwa memang kelompok petani membutuhkan kelompok lain diluar kelompok petani yang dapat membangkitkan kesadaran kelas para petani tersebut, dan kemudian mengorganisasikannya menjadi suatu pergerakan.

Berbeda dengan konsep Marx yang melihat bahwa proses dominasi atau kekuasaan selalu dilakukan dengan caracara fisikal melalui pemaksaan, Gramsci (1971) melihatnya dengan cara yang berbeda. Kekuasaan tidak selalu dengan cara-cara yang sifatnya seperti itu tetapi juga dilakukan dengan menggunakan 'soft power'. 'Soft power' disini diartikan sebagai kekuatan untuk mempengaruhi kesadaran orang lain untuk melakukan sesuatu sesuai dengan permintaan kelas borjouis.

Soft power dilakukan dengan cara melalui dengan cara penanaman ideologi secara terus menerus kepada kelas pekerja sehingga mereka terbuai, dan mau mengerjakan apa yang diperintah oleh kaum borjousi. Gramsci kemudian mengatakan bahwa ada cara lain agar kelas pekerja atau kelas yang alienasi dapat sadar akan keadaan yang menimpanya atau disebut oleh Marx sebagai 'class consciousness' atau 'kesadaran kelas'(Lukacs, 1979).

Jika kita merujuk kepada apa yang disampaikan oleh Marx, kesadaran kelas akan diperoleh secara natural dari proses alienasi terus-menerus yang menekan kelas pekerja sehingga kemudian mereka menjadi tersadar. Dilain sisi Marx juga menyebutkan bahwa ada suatu masa, dimana kemudian kapitalis gagal dalam bekerja yaitu ketika pasar tidak dapat menampung produksi yang diproduksi secara masal dan harganyapun kemudian lambat laun menjadi murah dan tidak lagi menguntungkan. Marx kemudian mengatakan bahwa imperialism adalah jalan dipilih oleh capitalism untuk memperluas sumber daya sekaligus pasarnya. Kesadaran kelas bagi Marx adalah kondisi sadar kaum pekerja bahwa mereka ada kondisi teralienasi dari kelas kapitalis. Kesadaran kelas tersebut kemudian membuat mereka sadar untuk bergerak melawan untuk mencapai kondisi masyarakat yang tanpa kelas.

\section{Peran Intelektual}

$\mathrm{B}$ erbeda dengan Marx, Gramsci (1972) mempunyai pandangan bahwa tidak mungkin kesadaran kelas akan terjadi jika tidak disadarkan oleh orang lain. Proses penyadaran kelas tidak terjadi secara natural menurut Gramsci. Hal ini juga didukung oleh pandangan Lenin berdasarkan pengalamannya dalam revolusi Bolshevik. Bahwa revolusi harus diciptakan dan dipersiapkan sedemikian rupa. Namun yang membedakan pengalaman Lenin dan Gramsci adalah bahwa siapa yang sepatutnya memberikan penyadaran kelas terhadap kelas pekerja tersebut dan bagaimana caranya. Keduanya sepakat juga mengatakan bahwa kesadaran kelas memang sepatutnya digerakan oleh kaum dalam kelasnya tersendiri.

Namun perbedaannya adalah Gramsci menekankan kepada peran kaum intelektual dalam kaum pekerja untuk dapat memberikan penyadaran dan pencerahan kelas. Kaum intelektual ada dalam kelompok 'civil society' atau kelompok masyarakat yang ada diluar apparatus pemerintah dan kaum kapitalis. Golongan intelektual disini digambarkan oleh Gramsci adalah kelompok terpelajar yang mampu memberikan pencerahan dan penyadaran kepada kaum buruh bahwa mereka berada dalam kondisi teralianeasi atau disebutnya 'organic intellectual". Lenin memang menolak pandangan Gramsci bahwa kaum intelektual 
mempunyai kewajiban untuk melakukan penyadaran kelas terhadap kaum pekerja.

Menurut Lenin tidak akan mungkin golongan intelektual melakukan penyadaran karena dia adalah bagian besar dari kapitalis. Ternyata Gramsci juga telah menjelaskan proses ini dengan konsep hegemoni. Gramsci menyebutkan bahwa ada tipe intelektual yang bersifat 'traditional intellectual' atau intelektual yang menjadi kaki tangan kaum kapitalis atau apparatus pemerintah. Mereka sadar atau tidak sadar telah menjadi bagian dari tujuan besar kapitalis dan apparatus pemerintahan.

Gramsci juga mengatakan bahwa adalah tugas dari kaum intelektual untuk melakukan penyadaran kepada kaum pekerja atas kesadaran kelas bahwa dirinya hidup dalam alienasi yang akut. Perlawanan terhadap hegemoni kebudayaan inilah yang sesungguhnya menjadi tugas pokok golongan intelektual. Penyadaran kelas ini menurut Gramsci dilakukan dengan cara 'counter hegemony 'atas ideologi yang diterimanya.

Bourdieu dikemudian hari, menggunakan pendekatan ini dengan menyebutnya sebagai suatu dominasi simbolik atau 'symbolic dominance'. Bourdieu melihat bahwa kapitalisasi modal tidak hanya dilakukan dalam konteks material atau sesuatu yang sifatnya tangible tetapi juga sesuatu yang sifatnya symbolic atas dasar penyimbolan dari sesuatu yang dimiliki oleh seseorang berdasarkan peranan yang ada pada dirinya dalam masyarakat dimana dengan peranan yang dimilikinya tersebut ia mendapatkan status atau posisi social tertentu dalam masyarakat.

Perdebatan selanjutanya apakah benar golongan intelektual itu selalu ada dalam kelompok civil society, atau jikapun ada apakah mereka mau melakukan pekerjaan atau tugasnya sebagai orang yang memberikan penyadaran kelas terhadap kelas atau golongan yang teralienasi ?

\section{Pemimpin Yang Karismatik}

E ric Wolf (1969) dalam "Peasant War" mengatakan bahwa dalam sejarah pergerakan kaum petani ternyata tidak semuanya dipimpin atau digerakan oleh orang-orang yang mempunyai kelas yang sama atau asal yang sama. Dalam studinya, dari beberapa contoh kasus pergerakan kaum petani yang ada di Kuba, Cina dan beberapa Negara amerika latin, Wolf mengatakan adalah peran orang luar dari kaum pekerja atau kelompok lain sangat kuat untuk menyadarkan kaum petani yang teralineasi tersebut. la memberikan contoh dimana misalnya di Kuba dipimpin oleh Castro atau kelompoknya yang ternyata adalah orang-orang terdidik yang tidak berasal dari kelas pekerja namun dari kelas yang lebih kaya. Atau misalnya dalam kasus petani Cina. Maa Tse Tung bukanlah orang yang berasal dari kelas petani. Singkatnya Wolf mengatakan bahwa adalah tugas intelektual yang ada diluar kelompoklah yang mempunyai peran dalam membawa perubahan kesadaran kelas bagi masyarakatnya.

Wolf(1999) juga mengarisbawahi bahwa ternyata peran 'charismatic leader' adalah sangat krusial untuk memberikan dorongan atas perubahan itu. Karena 'charismatic leader' dapat memberikan dorongan perubahan kesadaran yang tidak dipunyai oleh kelompok lainnya. Dasarnya adalah bagaimana kharismatic leader membentuk kepercayaan orang yang mempercayainya untuk melakukan sesuatu.

Pemimpin yang karismatik ini sesungguhnya dibahas pula oleh Bourdieu (1990) dan Giddens (2013) yang disebut sebagai seseorang atau agen yang mempunyai peran untuk melakukan perubahan terhadap struktur. Berkaitan dengan ini Bourdieu mengatakan bahwa ada kondisi yang dibangun oleh orang yang punya kuasa untuk mempengaruhi orangorang lain untuk melakukan sesuatu sesuai dengan apa yang dikenhendakinya tanpa melakukan suatu tindakan. Struktur cara berpikir ini yang disebut oleh Bourdieu sebagai struktur objective. Jadi ada semacam kepercayaan yang ditanamkan kepada kelompoknya akan perubahan yang akan didapatkannya. Wolf (1999) kemudian melihat perlawanan melalui ideologi disini menjadi sangat penting untuk dilakukan.

Apa yang dikemukakan oleh Wolf, sesungguhnya sudah sejak lama diungkapkan oleh Weber. Weber sebenarnya seolah ingin mempertemukan gagasan Marxian dan Durkheim tentang social movement ini. la sejak awal melihat bahwa factor budaya sesungguhnya adalah 
sangat penting sebagai acuan untuk transformasi social. Meskipun Weber (dalam Weber, Gerth, \& Mills, 2009; Weber \& Kalberg, 2013)sendiri tidak menyebut sebagai budaya, sebagai "etic" atau etika. Dalam bukunya tentang etika protestan, Weber mengatakan bahwa etika atau norma budaya itu menjadi rujukan dalam transformasi social masyarakat - dari tradisional menuju modern. Factor itu mendorong ke arah perubahan social yang jelas dan terarah. la kemudian menjelaskan bahwa ada 3 faktor yang berpengaruh terhadap perubahan social tersebut yaitu (1) factor etika atau nilai budaya yang menjadi acuan, dan (2) kaum intelektual yang menjadi contoh panutan dan menyebarkan gagasan tentang modernisasi, dan yang ketiga (3) adalah karismatic leader yang menjadi pendorong akselarasi perubahan social tersebut.

Dalam konteks ini peran intelektual dalam perubahan sangatlah penting sebagai panutan dan yang menyadarkan serta menggerakan masyarakat pendukungnya, dan berdasarkan Wolf (1969), intelektual hadir dari kelas social yang berbeda. Karena merekalah yang mampu melihat penindasan dan menyadarkan kelas subordinate dari hegemoni.

\section{E. Kesimpulan}

A pabila Marx, melihat perubahan social adalah perubahan dari masyarakat dengan kelas social menuju ke masyarakat yang tanpa kelas, demikian pula dengan Durkheim yang melihat perubahan social sesungguhnya adalah proses penyesuaian menuju kesinambungan atau kondisi 'equilibrium', maka Weber meihat perubahan social adalah proses perubahan masyarakat dari tradisional menuju modern, dari bentuk yang sederhana menuju yang kompleks. Artinya Weber melihat social movement sebagai wahana untuk perubahan masyarakat, dan pemimpin serta kaum intelektual menjadi factor penting dalam perubahan itu.

Dalam pandangan Wolf (1999), kaum intelektual ini tidak menampakan dirinya (atau tidak ada) dalam kelompok peasant karena peasant bukanlah kelas yang mempunyai kesadaran dan kemampuan seperti kelas proletariat karena proses dominasi yang dikatakan Wolf diikuti oleh proses "dominance symbolic" dibelakang nya. Proses symbolic work ini yang membuat kerja dominasi oleh kelas dominan semakin kuat dan semakin dalam mempengaruhi kesadaran kelas peasant. bagi Wolf dibutuhkan sumber lain diluar kelas peasant untuk memunculkan kesadaran kelas dan mengorganisasikan kelas peasant untuk melawan kelas dominant. Disinilah peran leader (pemimpin) seperti yang dikatakan oleh Weber dan pengorganisasian menjadi penting karena menurut Wolf pendominasian dilakukan melalui structural power, atau kekuatan structural yang bekerja melalui struktur organisasi dan institusi social. Oleh karena itu perlawanan juga dilakukan melalui proses structural power dengan didukung oleh gagasan idelogi yang disebut oleh Wolf sebagai perlawanan symbolic. Dan peran itu yang telah diambil oleh para inteletual. Tidak sekedar akademik tetapi peran yang menyadarkan bagi orang lain.

\section{Daftar Pustaka}

Bottomore, Tom. (1979). Introduction. In T. Bottomore (Ed.), Karl Marx. Oxford: Blackwell Publishers.

Bourdieu, P. (1990). The Logic of Practice: Stanford University Press.

Giddens, A. (2013). The Constitution of Society: Outline of the Theory of Structuration: Wiley.

Gramsci, Andre. (1971). Selections from the prison notebooks of Antonio Gramsci (Q. Hoare \& G. Nowell-Smith, Trans. Q. Hoare \& G. Nowell-Smith Eds.): International Publishers.

Gramsci, Antonio. (1972). Prison Notebooks (J. A. Buttigieg, Trans. J. A. Buttigieg Ed. second ed.): Columbia University Press.

Israel, Joachim. (1979). Alienation: From Marx to Modern Sociology. New Jersey \& Sussex: Humanities Press \& Harvester Press. 
Lukacs, Georg. (1979). Class Consciouness. In T. Bottomore (Ed.), Karl Marx. Oxford: Blackwell Publishers.

Porta, D.D., \& Diani, M. (1999). Social Movements: An Introduction: Blackwell publishers Incorporated.

Sasson, Anne Showstack. (1980). Gramsci's Politics. London: Croom Helm London.

Tilly, Charles. (1978). From Mobilization to Revolution. New York: Newbery Award Records, Inc.

Weber, M., Gerth, H.H., \& Mills, C.W. (2009). From Max Weber: Essays in Sociology: Routledge.

Weber, M., \& Kalberg, S. (2013). The Protestant Ethic and the Spirit of Capitalism: Taylor \& Francis.

Wilkinson, Paul. (1971). Social Movement. London: Pall Mall Press Limited.

Wolf, E.R. (1969). Peasant wars of the twentieth century: University of Oklahoma Press.

Wolf, E.R. (1999). Envisioning power: ideologies of dominance and crisis: University of California Press. 